\title{
Inbreeding depression in maize populations and its effects on the obtention of promising inbred lines
}

\section{Depressão por endogamia em populações de milho e seus efeitos na obtenção de linhagens promissoras}

\author{
Deoclecio Domingos Garbuglio ${ }^{1 *}$; José Branco de Miranda Filho ${ }^{2}$; \\ Pedro Mário de Araújo ${ }^{1}$; Antonio Carlos Gerage ${ }^{1}$
}

\begin{abstract}
Inbreeding can potentially be used for the development of inbred lines containing alleles of interest, but the genetic causes that control inbreeding depression are not completely known, and there are few studies found in the literature. The present study aimed to obtain estimates of inbreeding depression for eight traits in seven tropical maize populations, analyze the effects of inbreeding over generations and environments, and predict the behavior of inbred lines in future generation $\mathrm{S}_{\infty}$ through linear regression methods. It was found that regardless of the base population used, prediction values could vary when the model was based on only 2 generations of inbreeding due to the environmental component. The influence of the environment in this type of study could be reduced when considering 3 generations of inbreeding, allowing greater precision in predicting the phenotypes of inbred lines. The use of linear regression was effective for inbred line prediction for the different agronomic traits evaluated. The use of 3 levels of inbreeding minimizes the effects of the environmental component in inbred line prediction for grain yield. GO-S was the most promising population for inbred line extraction.
\end{abstract}

Key words: Zea mays L. Linear regression. Selfing.

\section{Resumo}

A endogamia pode ser utilizada para o desenvolvimento de linhagens endogâmicas com alelos de interesse, porém as causas genéticas que a controlam não são completamente conhecidas. O presente estudo objetivou obter estimativas de depressão por endogamia para oito variáveis em sete populações de milho tropical, analisar o comportamento dos efeitos da endogamia sobre gerações e ambientes e prever o comportamento das linhagens na geração $\mathrm{S}_{\infty}$, por meio de métodos de regressão linear. Independentemente da população base utilizada, os valores de predição podem ser diferentes quando se consideram apenas dois níveis de endogamia, devido ao componente ambiental. A influência do ambiente neste tipo de estudo pode ser reduzida quando se consideram três níveis de endogamia, refletindo em maior precisão na predição das linhagens. O uso de regressão linear foi efetivo na predição de linhagens para as diferentes características agronômicas avaliadas. O uso de três níveis de endogamia minimiza os efeitos da componente ambiental na predição de linhagens puras para produtividade de grãos. GO-S foi a população mais promissora para a extração de linhagens.

Palavras-chave: Zea mays L. Regressão linear. Autofecundação.

\footnotetext{
${ }^{1}$ Pesquisadores, Área de Melhoramento e Genética Vegetal, Instituto Agronômico do Paraná, IAPAR, Londrina, PR, Brasil. E-mail: ddgarbuglio@iapar.br; pmaraujo@iapar.br; milhoger@iapar.br

2 Prof. Titular, Colaborador Sênior, Departamento de Genética, Escola Superior de Agricultura “Luiz de Queiroz", Universidade de São Paulo, ESALQ/USP, Piracicaba, SP, Brasil. E-mail: jbmiranda45@usp.br

* Author for correspondence
} 


\section{Introduction}

In genetic breeding of allogamous species, such as maize, the crossing of related individuals can cause damage to the offspring in some cases. This effect, called inbreeding depression, is characterized by a reduction in the mean values of quantitative traits related to the reproductive capacity or physiological efficiency of the plant due to the homozygosis of deleterious alleles (FALCONER, 1989).

The genetic causes that control it are not completely known, and there are some hypotheses to explain it. One of these explanations is linked to the fact that favorable genes tend to be dominant or partially dominant, and the second explanation is that the heterozygote has a higher phenotypic value than the homozygote (CROW; KIMURA, 1970). In particular, in the first case, inbreeding depression would then result from the breakdown of the ideal combination of the alleles that govern the trait in question.

From the point of view of genetic breeding, inbreeding can potentially be used for the development of inbred lines containing alleles of interest that are subsequently used in the case of maize in the composition of single, double, or three-way crosses or even in recurrent selection involving partially inbred lines $\left(\mathrm{S}_{1}, \mathrm{~S}_{2}\right.$ and $\left.\mathrm{S}_{3}\right)$ for the development of populations (HALLAUER et al., 2010).

Among the methods used by breeders to induce inbreeding, self-fertilization with row selection and double haploidization are the most important. Through selfing, selected inbred lines are now used in maize testcrosses from the $\mathrm{S}_{6}$ generation; however, they still present a percentage of $1.56 \%$ of heterozygosity. According to (PIERRE et al., 2011), although this percentage seems small, considering that a maize plant has more than 30 thousand genes, this number becomes significant. In the case of the use of double haploidization, the first generation will present $100 \%$ homozygous loci in inbred lines, but all segregation (including agronomically good and bad individuals) that would be selected by the breeder over multiple years if using the selfing method will be expressed in a single generation.

In this case, the increase in the probability of obtaining agronomically useful inbred lines is contingent on starting from genetically adequate populations, which means that these populations must present a high frequency of favorable alleles for several traits of interest, that is, a high general combining ability (MIRANDA FILHO; VIEGAS, 1987; VENCOVSKY; BARRIGA, 1992) with a small genetic load, meaning that the potential for inbreeding depression is small (VENCOVSKY; BARRIGA, 1992). These two conditions are correlated because populations or groups subjected to recurrent selection are expected to present a greater general combining ability with less inbreeding depression when selfed.

Despite the importance of studies on inbreeding in different traits of interest, there are few studies found in the literature, or when they exist, according to Botelho et al. (2016), the results vary in relation to the genotypes evaluated. Furthermore, the studies in the literature are mostly from the 1980s and 1990s.

Thus, the present study aimed to obtain estimates of inbreeding depression for eight agronomic traits in seven tropical maize populations, analyze the behavior of the effects of inbreeding over generations and environments, and predict the behavior of inbred lines in future generation $\mathrm{S}_{\infty}$ through linear regression methods in order to identify promising sources for tropical inbred line extraction.

\section{Material and Methods}

This study used 7 maize populations, whose origins and obtaining methods are described in Table 1, belonging to the Department of Genetics, ESALQ, along with samples of $\mathrm{S}_{1}$ and $\mathrm{S}_{2}$ families (seven samples from each population), totaling 21 treatments. The experimental design was randomized complete blocks with 3 replications. The 
trials were carried out in the locations of Londrina-

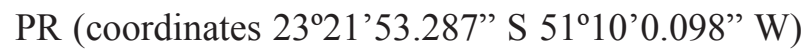
and Piracicaba-SP (coordinates 22\%42'25.636" S $47^{\circ} 38^{\prime} 10.316$ "W) during the 2006/2007 agricultural year. The experimental plot consisted of two rows of 5 meters in length, spaced $80 \mathrm{~cm}$ between rows, leaving 5 plants per meter after thinning, in order to reach a final stand equivalent to 62,500 plants.ha $^{-1}$.

Table 1. Populations used in this study and their respective origins.

GO-S: Material subjected to recurrent selection from the Suwan synthetic, which was introduced originally from Thailand and improved by EMBRAPA Maize and Sorghum, commercially known as variety BR 105 .
G3 and G4: Obtained through intercrossing between 5 base populations after selection for combining ability and heterotic pattern based on a complete diallel cross evaluation, among 28 populations.

GO-G, GO-L, GO-D and GO-F: Populations obtained by selection in experiments involving evaluation of half-sib families, full-sib families and hybrids from maize testcrosses and crossings involving $\mathrm{S}_{1}$ inbred lines (Rio Verde-GO-Brazil, 1994/1995 agricultural year) based on visual appearance for thick ears (GO-G), long ears (GO-L), dent grains (GO-D) and flint grains (GO-F).

The joint analysis followed the triple factorial model, taking as fixed the populations and locations and as random the inbreeding generations. The model used was $\mathrm{Y}_{\mathrm{i} q \mathrm{q} k}=\mu+\mathrm{p}_{\mathrm{i}}+\mathrm{g}_{\mathrm{j}}+\mathrm{l}_{\mathrm{q}}+(\mathrm{pg})_{\mathrm{ij}}+(\mathrm{pl})_{\mathrm{iq}}+(\mathrm{gl})_{\mathrm{jq}}+(\mathrm{pg})_{\mathrm{ijq}}+\mathrm{b}_{\mathrm{k}(\mathrm{iq})}+\bar{\varepsilon}_{\mathrm{ijqk}}$, where $\mathrm{Y}_{\mathrm{ijgk}}$ : observation of the $\mathrm{i}$-th population in the $\mathrm{j}$-th inbreeding generation at the q-th block and $\mathrm{k}$-th location; $\mu$ : overall mean of the trials; $b_{k(i q)}$ : effect of block $\mathrm{k}$ in the population $\mathrm{i}$ at the location $\mathrm{q} ; \mathrm{p}_{\mathrm{i}}$ : effect of population $\mathrm{i}$; $\mathrm{g}_{\mathrm{j}}$ : effect of inbreeding generation $\mathrm{j} ; \mathrm{l}_{\mathrm{q}}$ : effect of location $\mathrm{q}$; $(\mathrm{pg})_{\mathrm{ij}}$ : interaction effect between population $\mathrm{i}$ and generation $\mathrm{j}$; $(\mathrm{pl})_{\mathrm{iq}}$ : interaction effect between population $i$ and location $\mathrm{q} ;(\mathrm{gl})_{\mathrm{jq}}$ : interaction effect between generation $\mathrm{j}$ and location q; $(\mathrm{pgl})_{\mathrm{ijq}}$ : triple interaction effect between population i, generation $\mathrm{j}$ and location $\mathrm{q}$; and $\bar{\varepsilon}_{\mathrm{ijqk}}$; random error associated with observation ijqk.

The traits analyzed were as follows: ear diameter (ED), measured at the middle of the ear (cm), taking the average of five ears taken at random from the middle of the experimental plot; female flowering (FF), measured in days from emergence until the issue of style-stigmas in $50 \%$ of the experimental plot; plant height $(\mathrm{PH})$ and ear height $(\mathrm{EH})$, measured in $\mathrm{cm}$, taking the average of five plants at random from the middle of the experimental plot; ratio between $\mathrm{EH}$ and $\mathrm{PH}(\mathrm{EH} / \mathrm{PH})$, a dimensionless unit; grain moisture (GM), measured as a percentage; ear length (EL), measured in $\mathrm{cm}$, taking the average of five ears taken at random from the middle of the experimental plot; and grain yield (GY), obtained from the total yield of the experimental plot, adjusted to the initial stand of 50 plants according to the covariance method (VENCOVSKY; BARRIGA, 1992) and corrected to $\mathrm{kg} \mathrm{ha}^{-1}$ with $13.5 \%$ of moisture.

To determine the average differences between the inbreeding generations $\left(\mathrm{S}_{0}, \mathrm{~S}_{1}\right.$ and $\left.\mathrm{S}_{2}\right)$ in accordance with the effects of inbreeding and the intra-variable responses, cluster analysis was performed using the Scott-Knott method at 5\% probability. When predicting future line phenotypes $\left(\mathrm{S}_{\infty}\right)$, each of the locations was considered to have the same magnitude of environmental variance observed in the present study.

Whereas the rate of increase of homozygous loci follows a linear function for certain traits, we used linear regression models to predict the behavior of inbred lines in $\mathrm{S}_{\infty}$, not considering the effects of selection over the generations. Thus, it is possible to predict the potential of the inbred lines defined after " $n$ " selfings, considering the inbreeding coefficient of Wright, or fixation index $(\mathrm{F})$, being $\mathrm{F} \sim 1$, or even in cases of obtaining inbred lines through dihaploidization in which $\mathrm{F}=1$. 
This linear regression model considered the inbreeding levels for $\mathrm{S}_{0}, \mathrm{~S}_{1}$ and $\mathrm{S}_{2}$, represented by $0 \%, 50 \%$ and $75 \%$, respectively, as an independent variable. The equation is defined by $Y_{i}=\alpha+\beta X_{i}+e_{i}$, where $\mathrm{Y}_{\mathrm{i}}$ is the mean predicted for the generation of inbreeding; $\alpha$ represents the intercept of the line with the vertical axis, that is, it represents the general mean of the analyzed variable; $\beta$ is the angular coefficient or regression line, in this case, the variation of the predicted average $\left(\mathrm{Y}_{\mathrm{i}}\right)$ according to the variation of one unit of inbreeding $\left(\mathrm{X}_{\mathrm{i}}\right)$; $\mathrm{X}_{\mathrm{i}}$ is the $\mathrm{i}$-th level of the independent variable, in this case, the level of inbreeding $(\mathrm{i}=0 \%$, $50 \%, 75 \% \ldots 100 \%$ ); and $\mathrm{i}$ is the error associated with the distance between the value of $Y_{i}$ and its corresponding point on the line predicted by the model for the same level $i$ of $X$.

\section{Results and Discussion}

Through a joint analysis (Table 2), it was observed that the levels of depression due to inbreeding presented significant differences $(\mathrm{p}<0.05)$ for all traits, indicating that the overall means of inbreeding generations had at least one significant contrast among the populations. For $\mathrm{EH} / \mathrm{PH}$ and GM, as well as the general means by locations in relation to the $\mathrm{EH}, \mathrm{EH} / \mathrm{PH}$ and $\mathrm{ED}$ variables, no significant differences were detected; thus, it was possible to infer that the differences between the means for these sources of variation were due to random chance.

Table 2. Mean squares obtained by analysis of variance using the triple factorial model (2006/2007 agricultural year, in Londrina-PR and Piracicaba-SP locations).

\begin{tabular}{|c|c|c|c|c|c|c|c|c|c|}
\hline \multirow{2}{*}{$\mathrm{SV}$} & \multirow{2}{*}{$\mathrm{DF}$} & ED & \multicolumn{3}{|c|}{ FF } & $\mathrm{PH}$ & \multicolumn{3}{|c|}{$\mathrm{EH}$} \\
\hline & & $\mathrm{cm}$ & \multicolumn{3}{|c|}{ days } & \multicolumn{4}{|c|}{$-----------\mathrm{cm}----------$} \\
\hline Locations (L) & 1 & 0.000 & & 1092.4 & $* *$ & 1146.0 & $* *$ & 61.5 & \\
\hline Inbreeding (I) & 2 & 3.816 & $* *$ & 47.0 & $* *$ & $14,250.9$ & $* *$ & 8869.8 & $* *$ \\
\hline Populations (P) & 6 & 0.171 & $* *$ & 14.2 & $* *$ & 529.5 & $* *$ & 243.0 & $* *$ \\
\hline $\mathrm{L} \times \mathrm{I}$ & 2 & 0.031 & & 22.5 & $* *$ & 705.9 & $* *$ & 92.3 & \\
\hline $\mathrm{L} \times \mathrm{P}$ & 6 & 0.065 & $*$ & 5.0 & & 126.0 & & 119.2 & \\
\hline $\mathrm{I} \times \mathrm{P}$ & 12 & 0.019 & & 8.6 & $*$ & 59.3 & & 84.2 & \\
\hline $\mathrm{L} \times \mathrm{I} \times \mathrm{P}$ & 12 & 0.051 & $*$ & 6.0 & & 88.8 & & 98.9 & \\
\hline Error & 80 & 0.026 & & 3.4 & & 110.2 & & 72.9 & \\
\hline $\mathrm{CV} \%$ & & 3.76 & & 3.13 & & 5.64 & & 9.28 & \\
\hline General means & & 4.26 & & 59 & & 186 & & 92 & \\
\hline \multirow{2}{*}{$\mathrm{SV}$} & \multirow{2}{*}{ DF } & $\mathrm{EH} / \mathrm{PH}$ & & GM & & EL & & GY & \\
\hline & & & & $\%$ & & $\mathrm{~cm}$ & & $\mathrm{~kg} \mathrm{ha}^{-1}$ & \\
\hline Locations (L) & 1 & 0.0026 & & 903.48 & $* *$ & 248.84 & $* *$ & $2,492,613$ & $* *$ \\
\hline Inbreeding (I) & 2 & 0.0383 & $* *$ & 20.41 & $* *$ & 87.75 & $* *$ & $178,121,820$ & $* *$ \\
\hline Populations (P) & 6 & 0.0009 & & 0.45 & & 3.34 & $*$ & $2,356,661$ & $* *$ \\
\hline $\mathrm{L} \times \mathrm{I}$ & 2 & 0.0029 & & 0.49 & & 2.81 & & $2,453,298$ & $* *$ \\
\hline $\mathrm{L} \times \mathrm{P}$ & 6 & 0.0022 & & 0.20 & & 2.39 & & 830,975 & $*$ \\
\hline $\mathrm{I} \times \mathrm{P}$ & 12 & 0.0021 & & 0.64 & & 1.22 & & 907,541 & $* *$ \\
\hline $\mathrm{L} \times \mathrm{I} \times \mathrm{P}$ & 12 & 0.0019 & & 0.70 & & 2.00 & & 377,726 & \\
\hline Error & 80 & 0.0017 & & 0.39 & & 1.32 & & 327,633 & \\
\hline $\mathrm{CV} \%$ & & 8.31 & & 4.2 & & 7.34 & & 10.07 & \\
\hline General means & & 0.49 & & 14.9 & & 15.67 & & 5684 & \\
\hline
\end{tabular}

*,** significant at $1 \%$ and $5 \%$ probability by the $\mathrm{F}$ test, respectively. 
However, for ED, a significant interaction was detected between the test locations $\times$ populations used, as well as variation locations $\times$ inbreeding generations $\times$ populations. These facts indicate that populations showed different responses for ED due to environmental differences (location) and the level of inbreeding considered $\left(\mathrm{S}_{0}, \mathrm{~S}_{1}\right.$ or $\left.\mathrm{S}_{2}\right)$.

For FF and GY, inbreeding showed significant interaction with locations and populations, indicating that the means recorded for these traits varied according to the place of the test and the population used, due to the increase in homozygosity. For PH, inbreeding presented significant interaction $(p<0.01)$ in relation to locations, while for GY, in addition to inbreeding presenting significant interaction with locations, there was significance for locations $\times$ populations and inbreeding $\times$ populations $(\mathrm{p}<0.05)$.

These significant interactions indicated the need for a detailed analysis between and within sources of variation to better assess the distribution and groupings of the means (through the Scott-Knott method) or even to analyze the increase or decrease in these averages as a function of a regressive variable with fixed levels (levels of inbreeding) in order to establish equations that explain the pattern of future behavior of new inbred lines extracted from these populations.

As GY is a key variable that maize breeders wish to predict for future inbred lines, we sought to work with both simple regression analysis and clustering tests of means due to the significance of isolated variation sources and interactions. For the variables that presented some significant interactions (ED, FF and $\mathrm{PH}$ ), the Scott-Knott method was decomposed according to the interaction. For the other variables, where there was no significant interaction but the effect of inbreeding was significant $(\mathrm{EH}, \mathrm{EH} / \mathrm{PH}$, $\mathrm{GM}$ and EL), a general linear regression equation was performed for the set of populations.

For the inbreeding in ED (Table 3), there was a reduction in the overall means from $\mathrm{S}_{0}(4.56$ $\mathrm{cm})$ to $\mathrm{S}_{2}(3.96 \mathrm{~cm})$, in the range of $-13.1 \%$. The effects of inbreeding varied with the population and the site; in Londrina, only in $\mathrm{S}_{2}$ did distinct population groups form, while in Piracicaba, the formation of different groups occurred at all three levels of inbreeding, showing the influence of the environmental component on the expression of a trait under different levels of inbreeding.

In this sense, it is possible to visualize that for inbreeding coefficients $\mathrm{F}=0$ and $\mathrm{F}=0.5$ (corresponding to the $\mathrm{S}_{0}$ and $\mathrm{S}_{1}$ inbreeding generations), estimates of inbreeding depression may vary according to locations, populations and the inbreeding level considered. For $\mathrm{F}=0.75$ (corresponding to the $\mathrm{S}_{2}$ generation), the clustering differences were directly dependent on the genetic structures of the populations evaluated.

Regarding the general means for ED, it was verified that the GO-S population remained in the group with higher means of ear diameter, which implies that selection in the population based on this trait had been sufficient to maintain or increase the frequency of favorable alleles for this characteristic, which was reflected in smaller average ED reductions due to the increased homozygosity.

Regarding the traits $\mathrm{FF}$ and $\mathrm{PH}$, there was a significant effect of locations, which may be associated with differences in the average temperatures observed between the emergence periods and flowering. Higher degree-day values were detected in Piracicaba from emergence to flowering, with 863 degree-days, while Londrina presented 828 degree-days for the same period considered (data obtained from the Agrometeorology Area of IAPAR and the Meteorological Station of ESALQ). Bergamaschi and Matzenauer (2014) noted that thermal conditions influence several plant life processes, from germination and emergence to phenological development and growth of plants as a whole, either by soil or air temperature. 
Table 3. Cluster analysis using the Scott-Knott method for the source of variation Locations $\times$ Inbreeding Generations $\times$ Populations, showing a significant interaction effect for the trait ear diameter $(\mathrm{cm})$ by the Scott-Knott method at $5 \%$ probability (2006/2007 agricultural year).

\begin{tabular}{|c|c|c|c|c|c|c|c|}
\hline \multicolumn{8}{|c|}{$S_{0}$ generation } \\
\hline & Londrir & & & Piracicab & & & \\
\hline GO-S & 4.53 & $\mathrm{a}$ & $\mathrm{A}$ & 4.73 & $\mathrm{a}$ & $\mathrm{A}$ & \\
\hline G3 & 4.67 & $\mathrm{a}$ & A & 4.67 & $\mathrm{a}$ & A & $\mathbf{S}_{0}$ \\
\hline G4 & 4.55 & $\mathrm{a}$ & A & 4.47 & $\mathrm{~b}$ & A & Mean \\
\hline GO-G & 4.51 & $\mathrm{a}$ & A & 4.73 & $\mathrm{a}$ & A & $4.56 \mathrm{a}$ \\
\hline GO-L & 4.43 & $\mathrm{a}$ & A & 4.47 & $\mathrm{~b}$ & A & \\
\hline GO-D & 4.66 & $\mathrm{a}$ & A & 4.53 & $\mathrm{~b}$ & A & \\
\hline GO-F & 4.52 & $\mathrm{a}$ & $\mathrm{A}$ & 4.40 & $\mathrm{~b}$ & A & \\
\hline \multicolumn{8}{|c|}{$S_{1}$ generation } \\
\hline \multicolumn{4}{|c|}{ Londrina } & \multicolumn{3}{|c|}{ Piracicaba } & \\
\hline GO-S & 4.19 & $\mathrm{a}$ & B & 4.60 & $\mathrm{a}$ & A & \\
\hline G3 & 4.39 & $\mathrm{a}$ & A & 4.20 & $\mathrm{~b}$ & A & $S_{1}$ \\
\hline G4 & 4.17 & $\mathrm{a}$ & A & 4.27 & $\mathrm{~b}$ & A & Mean \\
\hline GO-G & 4.19 & $\mathrm{a}$ & A & 4.20 & $\mathrm{~b}$ & A & $4.25 \mathrm{~b}$ \\
\hline GO-L & 4.33 & $\mathrm{a}$ & A & 4.13 & $\mathrm{~b}$ & A & \\
\hline GO-D & 4.30 & $\mathrm{a}$ & A & 4.27 & $\mathrm{~b}$ & A & \\
\hline GO-F & 4.01 & $\mathrm{a}$ & A & 4.20 & $\mathrm{~b}$ & $\mathrm{~A}$ & \\
\hline \multicolumn{8}{|c|}{$\mathrm{S}_{2}$ generation } \\
\hline & \multicolumn{3}{|c|}{ Londrina } & \multicolumn{3}{|c|}{ Piracicaba } & \\
\hline GO-S & 4.04 & $\mathrm{a}$ & A & 4.07 & $\mathrm{a}$ & $\mathrm{A}$ & \\
\hline G3 & 4.17 & $\mathrm{a}$ & A & 4.10 & $\mathrm{a}$ & A & $\mathrm{S}_{2}$ \\
\hline G4 & 4.09 & $\mathrm{a}$ & A & 3.67 & $\mathrm{~b}$ & $\mathrm{~B}$ & Mean \\
\hline GO-G & 4.13 & $\mathrm{a}$ & A & 3.93 & $\mathrm{a}$ & A & $3.96 \mathrm{c}$ \\
\hline GO-L & 3.83 & $\mathrm{~b}$ & A & 4.00 & $\mathrm{a}$ & A & \\
\hline GO-D & 4.04 & $\mathrm{a}$ & A & 3.93 & $\mathrm{a}$ & A & \\
\hline GO-F & 3.64 & $\mathrm{~b}$ & A & 3.80 & $\mathrm{~b}$ & A & \\
\hline
\end{tabular}

Results with the same uppercase letters in the horizontal rows and lowercase letters in the vertical columns do not differ by ScottKnott's test at 5\% probability.

As maize is a $\mathrm{C}_{4}$ plant, it has a photosynthetic rate greater than those of $\mathrm{C}_{3}$ species in conditions of high temperatures (BERGAMASCHI; MATZENAUER, 2014), and although solar radiation and water can influence the phenology of maize, according to Coelho and Dale (1980), the sum of degree-days has a linear relationship with the development of plants. As described by Daughtry et al. (1984), through this relationship, it is possible to predict critical periods of the crop, such as dates of flowering and maturation, allowing the scheduling of management practices and the use of modeling. It was possible to observe that in Piracicaba, the plants presented a reduced cycle and larger mean $\mathrm{PH}$ (Tables 3 and 4), while in relation to the general means, the GO-S population tended earlier with reduced $\mathrm{PH}$.

In determining the distribution of $\mathrm{FF}$ means according to the inbreeding level and the evaluation sites (Table 4), it is possible to observe that maize plants tend to flower later $(3.45 \%$ in relation to the general average) as the level of homozygosity increases, as highlighted by Hallauer (1990) and Good and Hallauer (1977). The effect of sites was evident since there was a non-significant effect $(p>0.05)$ between levels of inbreeding within Londrina. 
Table 4. Cluster analysis using the Scott-Knott method for the sources of variation Locations $\times$ Inbreeding Generations and Inbreeding Generations $\times$ Populations, showing significant interaction effects for the trait female flowering (days) (2006/2007 agricultural year).

\begin{tabular}{|c|c|c|c|c|c|c|c|c|}
\hline & Londrina & & Piracic & & & & & \\
\hline S0 & $\begin{array}{ll}61 & \mathrm{a}\end{array}$ & $\mathrm{A}$ & 55 & $\mathrm{~b}$ & B & & & \\
\hline S1 & $61 \mathrm{a}$ & A & 54 & b & B & & & \\
\hline \multirow[t]{2}{*}{ S2 } & $62 \mathrm{a}$ & A & 58 & $\mathrm{a}$ & B & & & \\
\hline & \multicolumn{2}{|l|}{$S_{0}$} & \multicolumn{3}{|c|}{$S_{1}$} & \multicolumn{3}{|l|}{$\mathbf{S}$} \\
\hline GO-S & $56 \mathrm{~b}$ & B & 55 & $\mathrm{~b}$ & $B$ & 60 & $a$ & $\mathrm{~A}$ \\
\hline G3 & $58 \mathrm{~b}$ & A & 59 & $\mathrm{a}$ & A & 60 & $\mathrm{a}$ & A \\
\hline G4 & $57 \mathrm{~b}$ & B & 57 & b & B & 61 & $\mathrm{a}$ & A \\
\hline GO-G & $61 \mathrm{a}$ & A & 59 & $\mathrm{a}$ & A & 58 & $\mathrm{a}$ & A \\
\hline GO-L & $59 \quad \mathrm{a}$ & A & 58 & $\mathrm{a}$ & A & 60 & $\mathrm{a}$ & A \\
\hline GO-D & $60 \mathrm{a}$ & A & 59 & $\mathrm{a}$ & A & 60 & $\mathrm{a}$ & A \\
\hline GO-F & $58 \quad \mathrm{~b}$ & B & 57 & $\mathrm{~b}$ & B & 60 & $\mathrm{a}$ & A \\
\hline
\end{tabular}

Results with the same uppercase letters in the horizontal rows and lowercase letters in the vertical columns do not differ by ScottKnott's test at 5\% probability.

Among populations, significant differences $(p<0.05)$ were found within the $S_{0}$ and $S_{1}$ levels but not in $\mathrm{S}_{2}$. The populations that showed means of 60 days in $\mathrm{S}_{0}$ (GO-G and GO-L GO-G-D) remained the same with increasing homozygosity. For the other populations, the earliest in $\mathrm{S}_{0}$ tended to increase the number of days to flowering in $\mathrm{S}_{2}$, matching the others. Although the populations studied originated from distinct tropical germplasms and were obtained through different selection methods, there was an overall stabilization and convergence on a certain flowering time when $75 \%$ homozygosity was reached. It should be emphasized that the model studied does not predict selection because it considers the general behavior of the set of inbred lines, so it is possible that for a given population, there exist early and late individuals that can be selected.

For PH (Table 5), $\mathrm{S}_{0}$ to $\mathrm{S}_{2}$ inbreeding depression rates were found to be $-14.1 \%$ and $-21.1 \%$ in
Londrina and Piracicaba, respectively. Garbuglio et al. (2009), studying the genetic variability in these same populations with different sets of $\mathrm{S}_{1}$ families (and a different number of families), also found results of inbreeding depression below 20\% for PH. Similar results were verified by Senhorinho et al. (2015) when studying the effects of inbreeding depression in 22 commercial hybrids. In a work with popcorn carried out by Scapim et al. (2006), the researchers showed a predominance of additive effect and an inbreeding depression of $10 \%$ for plant height and ear height. In the present study, for the group of populations evaluated, there were differences in the phenotypic expression of $\mathrm{PH}$ due to the different conditions of the growing environments. These differences were concentrated in the $\mathrm{S}_{0}$ generation; as with $\mathrm{FF}$, there was a stabilization of the means in the $S_{2}$ between locations (for $\mathrm{PH}$ ) and among populations (for FF). 
Table 5. Cluster analysis using the Scott-Knott method for the source of variation Locations $\times$ Inbreeding Generations, showing significant interaction effects for the trait plant height (cm) (2006/2007 agricultural year).

\begin{tabular}{lrrrrrr}
\hline & Londrina & \multicolumn{3}{c}{ Piracicaba } \\
\hline $\mathbf{S}_{\mathbf{0}}$ & 199 & a & A & 213 & a & B \\
$\mathbf{S}_{1}$ & 180 & b & A & 186 & b & A \\
$\mathbf{S}_{2}$ & 171 & c & A & 168 & c & A \\
\hline
\end{tabular}

Results with the same uppercase letters in the horizontal rows and lowercase letters in the vertical columns do not differ by ScottKnott's test at 5\% probability.

Considering the rate of depression from $\mathrm{S}_{0}$ to $\mathrm{S}_{1}$ for $\mathrm{PH}$ and $\mathrm{FF}$, the results were slightly divergent from those cited by Hallauer (1990), where the author indicates that on average, plant height was reduced by $25 \%$, and the number of days for flowering increased by an average of $6.8 \%$. For FF, it is important to consider that the author worked with temperate genetic material, while the genetic backgrounds used in the present work are all tropical, which may explain the fact that materials had a cycle of approximately 59 to 60 days in $\mathrm{S}_{0}$ and tended not to show an increase in the number of days to flowering in the $S_{1}$ and $S_{2}$ generations.

According to Miranda Filho (2001), another explanation for the variation in the estimates of inbreeding depression for FF may be associated in part with the degree of relationship between the genotypes; closer genetic relationships may lead to greater effects of inbreeding depression.

For the other traits in which no interaction between the sources of variation was detected but inbreeding variation was significant, general linear equations were estimated (Figure 1) with respective coefficients of determination $\left(\mathrm{R}^{2}\right)$ to analyze the average response of the traits to the increase in homozygosity. For all traits, the $\mathrm{R}^{2}$ remained above $80 \%$, which indicates good accuracy of the model.

The means of inbreeding depression for $\mathrm{EH}$ (Figure 1A) were $15 \%$ for $S_{0} \rightarrow S_{1}$ and $27.1 \%$ for
$\mathrm{S}_{0} \rightarrow \mathrm{S}_{2}$. The EH/PH ratio (Figure $1 \mathrm{~B}$ ) showed reductions of $3.9 \%$ and $11.5 \%$ from $\mathrm{S}_{0}$ to $\mathrm{S}_{1}$ and $\mathrm{S}_{2}$, respectively. That is, even though there were reductions in both plant height and ear height, the relative insertion point presented a continuous reduction since the depression levels were not linear for the $\mathrm{PH}$ and $\mathrm{EH}$ variables when taken together, and in $\mathrm{EH}$, there was a higher level of depression both in $\mathrm{S}_{0} \rightarrow \mathrm{S}_{1}$ and $\mathrm{S}_{0} \rightarrow \mathrm{S}_{2}$.

The loss of grain moisture (Figure 1C) was accelerated as a result of the increase in the homozygosity level, on the order of $7 \%$ for $\mathrm{S}_{0} \rightarrow \mathrm{S}_{1}$ and of $8.3 \%$ for $\mathrm{S}_{0} \rightarrow \mathrm{S}_{2}$. The ear length (Figure 1D) was reduced by $10.6 \%$ in $\mathrm{S}_{0} \rightarrow \mathrm{S}_{1}$ and by $16.6 \%$ in $\mathrm{S}_{0} \rightarrow \mathrm{S}_{2}$.

Lopes et al. (2007), while evaluating several traits in maize crops, found a high positive correlation between ED and grain length and a low correlation between EL and grain size. In this study, we detected a reduction in ED in $\mathrm{S}_{1}$ and $\mathrm{S}_{2}$, and we would thereby expect a reduction in grain size, which, due to a smaller area, would reduce the time to loss of water, explaining the low values for GM detected in $\mathrm{S}_{1}$ and $\mathrm{S}_{2}$.

For GY (Table 6), as expected, three distinct groups of inbreeding levels were detected, within each evaluation site and between sites, with average rates of $35.6 \%$ inbreeding variation for $\mathrm{S}_{0} \rightarrow \mathrm{S}_{1}$ and of $50.3 \%$ for $\mathrm{S}_{0} \rightarrow \mathrm{S}_{2}$. 
Figure 1. Linear regression analysis for the traits ear height $(\mathrm{EH})$, ear height/plant height $(\mathrm{EH} / \mathrm{PH})$, grain moisture (GM) and ear length (EL), evaluated in two locations (Londrina-PR and Piracicaba) (2006/2007 agricultural year).

A

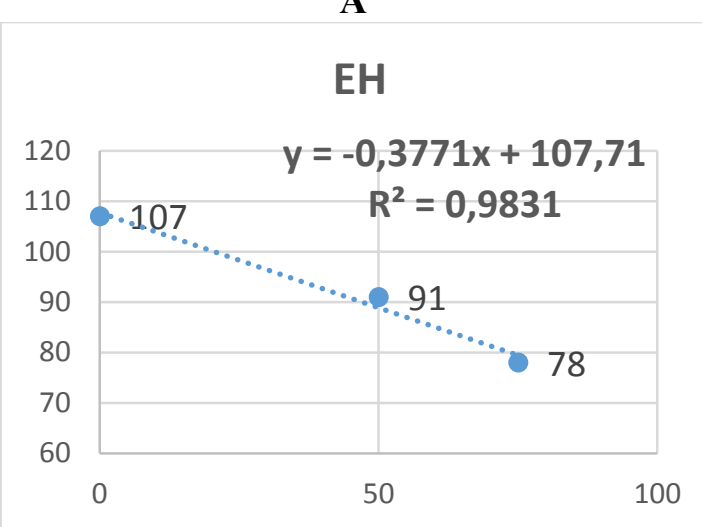

C

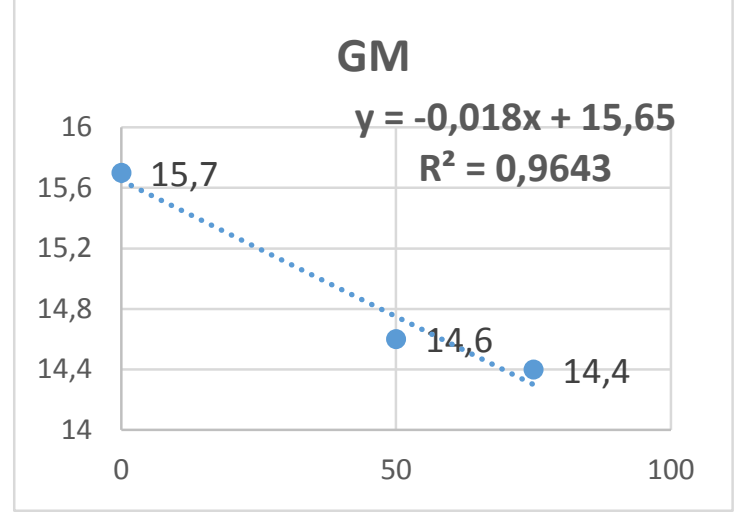

B

\section{$\mathrm{EH} / \mathrm{PH}$}

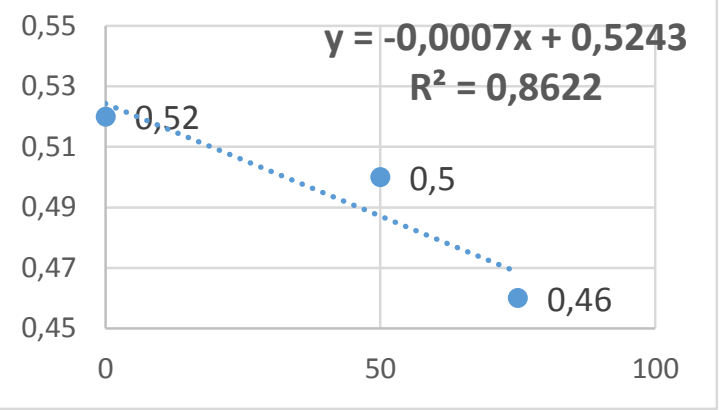

D

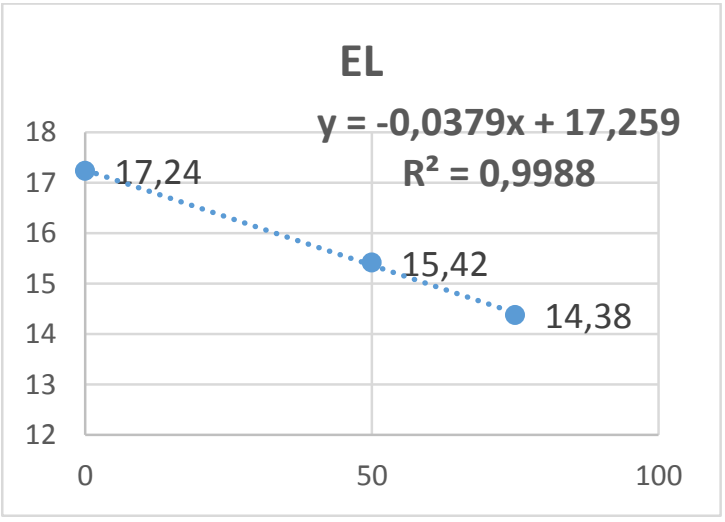

Table 6. Cluster analysis using the Scott-Knott method for Locations $\times$ Inbreeding Generations and Locations $\times$ Populations, showing significant interaction effects for the trait grain yield (GY) in kg ha ${ }^{-1}$ (2006/2007 agricultural year).

\begin{tabular}{|c|c|c|c|c|c|c|}
\hline \multirow[b]{2}{*}{ So } & \multicolumn{3}{|c|}{ Londrina } & \multicolumn{3}{|c|}{ Piracicaba } \\
\hline & 8175 & $\mathrm{a}$ & A & 7752 & $\mathrm{a}$ & B \\
\hline S1 & 5003 & $\mathrm{~b}$ & A & 5260 & $\mathrm{~b}$ & A \\
\hline \multirow[t]{2}{*}{$\mathbf{S 2}$} & 4296 & $\mathrm{c}$ & A & 3618 & $\mathrm{c}$ & B \\
\hline & \multicolumn{3}{|c|}{ Londrina } & Piracical & & \\
\hline GO-S & 6464 & $\mathrm{a}$ & $\mathrm{A}$ & 6257 & $\mathrm{a}$ & A \\
\hline G3 & 5901 & $\mathrm{~b}$ & A & 5456 & $\mathrm{~b}$ & A \\
\hline G4 & 5626 & $\mathrm{~b}$ & A & 5382 & $\mathrm{~b}$ & A \\
\hline GO-G & 5686 & $\mathrm{~b}$ & A & 5136 & $\mathrm{~b}$ & B \\
\hline GO-L & 5765 & $\mathrm{~b}$ & A & 6194 & $\mathrm{a}$ & A \\
\hline GO-D & 5905 & $\mathrm{~b}$ & A & 4970 & $\mathrm{~b}$ & B \\
\hline GO-F & 5424 & $b$ & A & 5407 & $\mathrm{~b}$ & A \\
\hline
\end{tabular}

Results with the same uppercase letters in the horizontal rows and lowercase letters in the vertical columns do not differ by ScottKnott's test at 5\% probability. 
Among the populations, GO-S and GO-L stood out because GO-S remained in the highest grain yield group within each site and both GO-S and GO-L remained high within each of the levels of inbreeding tested (Figure 2). This finding confirms that the best populations in the $\mathrm{S}_{0}$ generation, even when obtained by different populations and breeding methods, may have a high frequency of favorable alleles and tend to maintain their high performance over the selfing cycles, which increases the probability of obtaining inbred lines with agronomically good grain yield traits. The other populations remained in a second group when considering the overall means within the $\mathrm{S}_{1}$ and $\mathrm{S}_{2}$ levels (Figure 2).

Figure 2. Cluster analysis using the Scott-Knott method at $5 \%$ probability for Inbreeding Generations $\times$ Populations, showing significant interaction levels for the trait grain yield (GY) in $\mathrm{kg} \mathrm{ha}^{-1}$. Lowercase letters refer to the groupings of means between generations of inbreeding within each population and uppercase letters refer to population groupings within each generation of inbreeding.

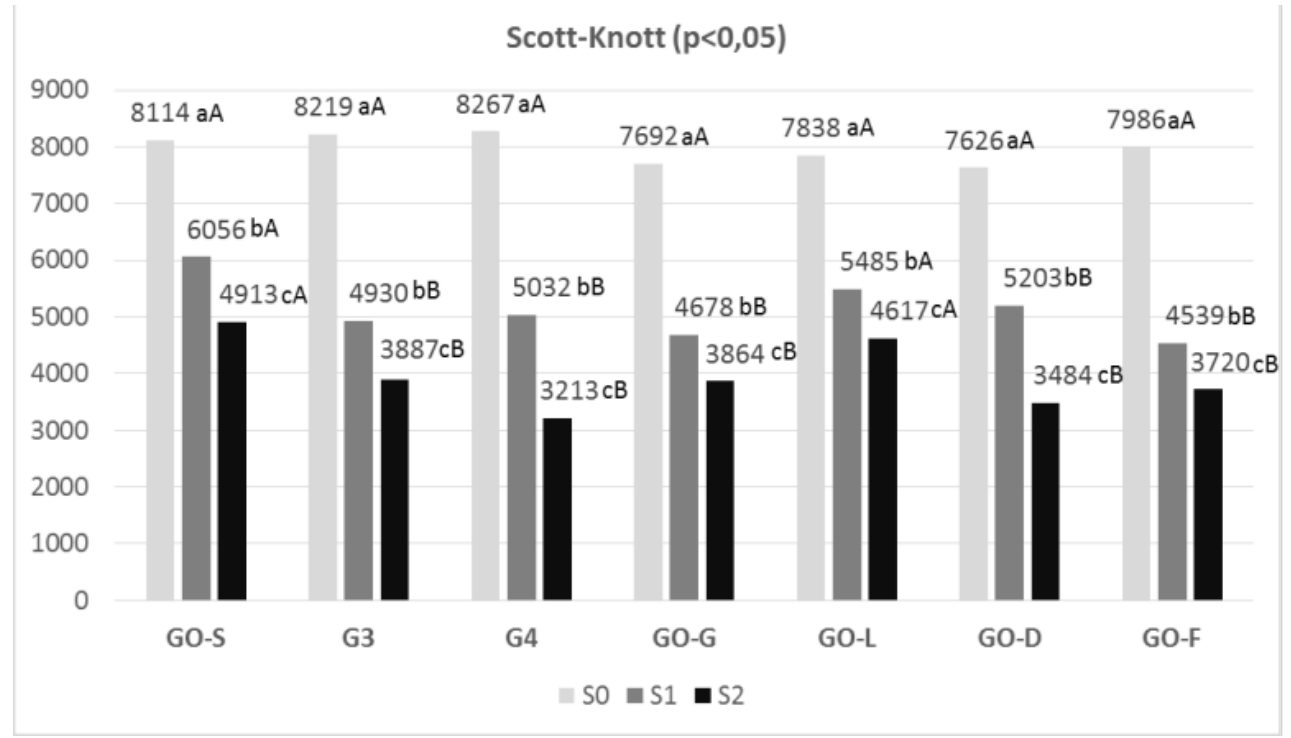

Through regression analysis (Table 7), the significance of $\beta$ (linear regression coefficient) and the non-significance of the regression deviation indicated that is possible to explain the increase in homozygosity levels by a linear model. Only the G4 population showed significant deviation in both locations, while GO-F and GO-D showed significant deviations in only one location. This fact might be due to one of the inbreeding levels presenting more pronounced responses to environmental differences. However, the $\mathrm{R}^{2}$ values, which are related to the accuracy of the mathematical model adopted, were above $90 \%$ for all populations within each trial location, indicating that the linear model was efficient in modeling the decrease in grain yield means due to the effects of inbreeding.

By analyzing inbreeding depression rates (Table 8) through the traditional method, which considers only the $\mathrm{S}_{0}$ and $\mathrm{S}_{1}$ levels, and the regression method, which used all 3 levels of inbreeding, it was found that the G4 population had the lowest predicted mean among the inbred lines when grown in Londrina through both methods. However, in Piracicaba, these analytical methods disagreed; the G4 population was in the group with higher grain yield when considering 2 levels of inbreeding and in the one with lower yield when considering 3 levels of inbreeding. 


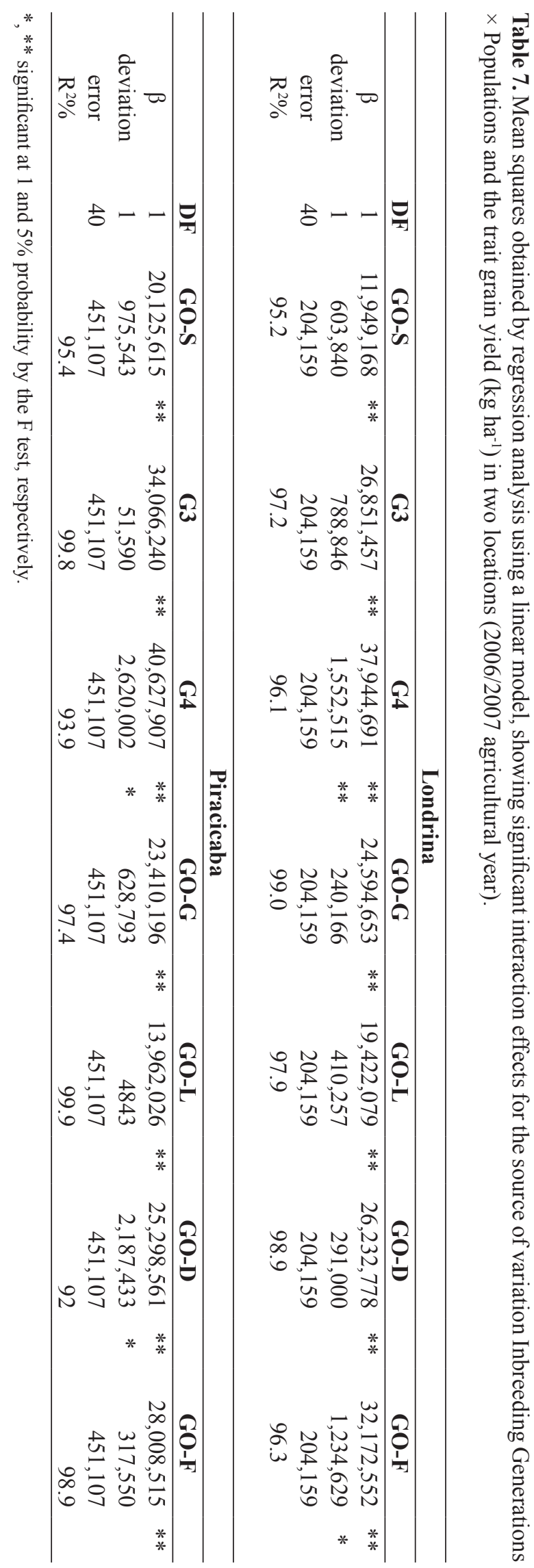


Table 8. Prediction of the average behavior of inbred lines for the grain yield trait by the traditional method with 2 inbreeding levels $\left(\mathrm{S}_{0}\right.$ and $\left.\mathrm{S}_{1}\right)$ and by linear regression with 3 levels of inbreeding $\left(\mathrm{S}_{0}, \mathrm{~S}_{1}\right.$ and $\left.\mathrm{S}_{2}\right)$. Cluster analysis was performed using the Scott-Knott method at $5 \%$ probability.

\begin{tabular}{|c|c|c|c|c|c|c|c|}
\hline \multicolumn{8}{|c|}{ Londrina } \\
\hline & \multicolumn{3}{|c|}{$S_{0}$ and $S_{1}$} & \multicolumn{4}{|c|}{$S_{0}, S_{1}$ and $S_{2}$} \\
\hline & \multicolumn{2}{|c|}{$\mathrm{L}=\mathrm{m}+\mathrm{a}$} & \multirow{2}{*}{$\begin{array}{c}\text { i.d. } \%\left(\mathrm{~S}_{0} \rightarrow \mathrm{S}_{1}\right) \\
28.6\end{array}$} & \multirow{2}{*}{$\begin{array}{c}\text { Linear Equation } \\
\mathrm{Y}_{\mathrm{i}}=8004-36.954 \mathrm{X}_{\mathrm{i}}\end{array}$} & \multicolumn{2}{|c|}{$\mathrm{L}=100 \%$} & \multirow{2}{*}{$\begin{array}{c}\text { i.d. } \%\left(\mathrm{~S}_{0} \rightarrow \mathrm{S}_{2}\right. \\
32.6\end{array}$} \\
\hline GO-S & 3470 & $\mathrm{a}$ & & & 4309 & $\mathrm{a}$ & \\
\hline G3 & 1710 & $\mathrm{~b}$ & 39.8 & $\mathrm{Y}_{\mathrm{i}}=8209-55.396 \mathrm{X}_{\mathrm{i}}$ & 2669 & $\mathrm{~b}$ & 48.1 \\
\hline G4 & 440 & $\mathrm{c}$ & 47.4 & $\mathrm{Y}_{\mathrm{i}}=8370-65.852 \mathrm{X}_{\mathrm{i}}$ & 1785 & $\mathrm{c}$ & 55.4 \\
\hline GO-G & 2065 & $\mathrm{~b}$ & 37.0 & $\mathrm{Y}_{\mathrm{i}}=7895-53.017 \mathrm{X}_{\mathrm{i}}$ & 2593 & $\mathrm{~b}$ & 48.9 \\
\hline GO-L & 2325 & $\mathrm{~b}$ & 35.1 & $Y_{i}=7729-47.113 X_{i}$ & 3018 & $\mathrm{~b}$ & 43.9 \\
\hline GO-D & 2128 & $\mathrm{~b}$ & 37.1 & $\mathrm{Y}_{\mathrm{i}}=8187-54.754 \mathrm{X}_{\mathrm{i}}$ & 2712 & $\mathrm{~b}$ & 48.6 \\
\hline GO-F & 686 & $\mathrm{c}$ & 45.8 & $\mathrm{Y}_{\mathrm{i}}^{1}=7950-60.637 \mathrm{X}_{\mathrm{i}}^{1}$ & 1886 & $\mathrm{c}$ & 53.9 \\
\hline \multicolumn{8}{|c|}{ Piracicaba } \\
\hline & \multicolumn{3}{|c|}{$S_{0}$ and $S_{1}$} & \multicolumn{4}{|c|}{$S_{0}, S_{1}$ and $S_{2}$} \\
\hline & \multicolumn{2}{|c|}{$\mathrm{L}=\mathrm{m}+\mathrm{a}$} & i.d. $\%\left(\mathrm{~S}_{0} \rightarrow \mathrm{S}_{1}\right)$ & Linear Equation & \multicolumn{2}{|c|}{$\mathrm{L}=100 \%$} & i.d. $\%\left(\mathrm{~S}_{0} \rightarrow \mathrm{S}_{2}\right)$ \\
\hline GO-S & 4527 & $\mathrm{a}$ & 22.1 & $\mathrm{Yi}=8256-47.959 \mathrm{Xi}$ & 3460 & $\mathrm{a}$ & 46.3 \\
\hline G3 & 1571 & $\mathrm{~b}$ & 40.3 & $\mathrm{Yi}=8056-62.396 \mathrm{Xi}$ & 1816 & $\mathrm{~b}$ & 57.4 \\
\hline G4 & 3155 & $\mathrm{a}$ & 30.2 & $\mathrm{Yi}=8221-68.141 \mathrm{Xi}$ & 1407 & $\mathrm{~b}$ & 67.2 \\
\hline GO-G & 1262 & $\mathrm{~b}$ & 41.5 & $\mathrm{Yi}=7291-51.725 \mathrm{Xi}$ & 2119 & $\mathrm{~b}$ & 50.7 \\
\hline GO-L & 3940 & $\mathrm{a}$ & 24.9 & $\mathrm{Yi}=7859-39.946 \mathrm{Xi}$ & 3864 & $\mathrm{a}$ & 38.3 \\
\hline GO-D & 3430 & $\mathrm{a}$ & 25.4 & $\mathrm{Yi}=7210-53.77 \mathrm{Xi}$ & 1833 & $\mathrm{~b}$ & 61.0 \\
\hline GO-F & 1497 & $\mathrm{~b}$ & 40.5 & $\mathrm{Yi}=7764-56.577 \mathrm{Xi}$ & 2106 & $\mathrm{~b}$ & 52.9 \\
\hline
\end{tabular}

Results with the same letters do not differ by Scott-Knott's test at $5 \%$ probability. $\mathrm{L}=\mathrm{m}+\mathrm{a}$ refers to the inbred line value predicted using data from 2 inbreeding generations, in which " $\mathrm{m}$ " is a general mean and "a" is the contribution of the homozygous loci. $\mathrm{L}=100 \%$ : refers to the predicted inbred line value using the linear equation with $\mathrm{X}_{\mathrm{i}}=100$ and $\alpha$ and $\beta$ calculated using data from 3 inbreeding generations. i.d: inbreeding depression.

In this case, in Londrina, the use of only the $\mathrm{S}_{0}$ and $\mathrm{S}_{1}$ series was sufficient to predict the inbred lines' behavior efficiently, while in Piracicaba, an additional generation of inbreeding was required to express the deleterious effects of homozygosity in the population, which was reflected in a predicted reduction in $\mathrm{S}_{2}$ on the order of $-67.2 \%$.

The GO-D population presented the same grouping pattern in Londrina when considering both 2 and 3 levels of inbreeding, but in Piracicaba, the predicted behavior of the inbred lines was similar to that of G4. In these cases where populations changed grain yield classifications, it was necessary to assess all 3 levels of inbreeding to that the prediction was more efficient.

For the G3, GO-G, GO-L, GO-S and GO-F populations, the use of 2 levels of inbreeding was efficient to predict the behavior of inbred lines in
Londrina since the behavior pattern was maintained when analyzed using 3 levels of inbreeding. The GO-S population remained in the group of higher grain yield independent of the location, whereas GO-L obtained this behavior pattern only in Piracicaba. GO-F presented the lowest mean of grain yield in Londrina, and G3 remained in the lower grain yield group in Piracicaba using both methods.

In this sense, it was noteworthy that regardless of the base population used, the prediction values could be different when considering only 2 levels of inbreeding due to the environmental component, which represents a complication in the prediction of inbred lines.

Considering that when both methods were used in Londrina and Piracicaba, assessing 3 levels of inbreeding presented more consistent results, 
it is reasonable to infer that the influence of the environment in this type of study can be reduced by considering 3 levels of inbreeding, leading to greater precision in the prediction of inbred lines.

\section{Conclusions}

For $\mathrm{PH}$ and $\mathrm{FF}$, there was a stabilization of means in the $\mathrm{S}_{2}$ generation.

The use of linear regression was effective in inbred line prediction for the different agronomic traits evaluated.

The use of 3 levels of inbreeding minimizes the effects of the environmental component in inbred line prediction for grain yield.

GO-S was the most promising population for inbred line extraction.

\section{Acknowledgments}

The authors gratefully acknowledge Coordination and Improvement of Higher Level or Education Personnel-CAPES and the Government of the State of Paraná for their financial support of the present project.

\section{References}

BERGAMASCHI, H.; MATZENAUER, R. Temperatura e fotoperíodo. In: . (Ed.). O milho e o clima. Porto Alegre: Emater/RS-Ascar, 2014. p. 33-46.

BOTELHO, F. B. S.; BRUZI, A. T.; LIMA, I. P.; RODRIGUES, C. S.; BOTELHO, R. T. C. Inbreeding depression in single, three way and double-cross hybrids of maize. Genetics and Molecular Research, Ribeirão Preto, v. 15, n. 3, p. 1-7, 2016.

COELHO, D. T.; DALE, R. F. An energy-crop growth variable and temperature function for predicting corn growth and development: planting to silking1. Agronomy Journal, Madison, v. 72, n. 3, p. 503-510, 1980.
CROW, J. F.; KIMURA, M. An introduction to population genetics theory. Minneapolis: Alpha Editions, 1970. 608 p.

DAUGHTRY, C. S. T.; COCHRAN, J. C.; HOLLINGER, S. E. Estimating silking and maturity dates of corn for large areas. Agronomy Journal, Madison, v. 76, n. 3, p. 415-420, 1984.

FALCONER, D. S. Introduction to quantitative genetics. $3^{\text {th }}$ ed. New York: Longman, 1989. 438 p.

GARBUGLIO, D. D.; MIRANDA FILHO, J. B.; CELLA, M. Variabilidade genética em famílias S1 de diferentes populações de milho. Acta Scientiarum, Maringá, v. 31, n. 2, p. 209-213, 2009.

GOOD, R. L.; HALLAUER, A. R. Inbreeding depression in maize by selfing and full-sibbing. Crop Science, Madison, v. 17, n. 6, p. 935-940, 1977.

HALLAUER, A. R. Methods used in developing maize inbreeds. Maydica, Bergamo, v. 35, n. 1, p. 1-16, 1990.

HALLAUER, A. R.; CARENA, M. J.; MIRANDA FILHO, J. B. Quantitative genetics in maize breeding. $3^{\text {th }}$ ed. New York: Springer New York, 2010. 663 p.

LOPES, S. J.; LÚCIO, A. D. C.; STORCK, L.; DAMO, H. P.; BRUM, B.; SANTOS, V. J. dos. Relações de causa e efeito em espigas de milho relacionadas aos tipos de híbridos. Ciência Rural, Santa Maria, v. 37, n. 6, p. 15361542, 2007.

MIRANDAFILHO,J.B. de.Endogamiae consaguinidade. In: NASS, L. L.;VALOIS, A. C. C.; MELO, I. S.; VALADARES-INGLIS, M. C. (Ed.). Recursos genéticos e melhoramento-plantas. Rondonopolis: Fundação MT, 2001. p. 629-671.

MIRANDA FILHO, J. B. de; VIEGAS, G. P. O milho hibrido. In: PATERNIANI, E.; VIEGAS, G. P. (Ed.). Melhoramento e produção de milho. Piracicaba: Fundação Cargill, 1987. v. 1, p. 277-340.

PIERRE, P. M. O.; DAVIDE, L. M. C.; COUTO, E. G. O.; SILVA, T. N.; RAMALHO, M. A. P.; SANTOS, J. B. Duplo-haploides: estratégias para obtenção e importância no melhoramento genético do milho. Revista Brasileira de Milho e Sorgo, Sete Lagoas, v. 10, n. 1, p. 1-16, 30 abr. 2011.

SCAPIM, C. A.; BRACCINI, A. de L.; PINTO, R. J. B.; AMARAL JUNIOR, A. T. do; RODOVALHO, M. de A.; SILVA, R. M. da; MOTERLE, L. M. Componentes genéticos de médias e depressão por endogamia em 
populações de milho-pipoca. Ciência Rural, Santa Maria, v. 36, n. 1, p. 36-41, 2006.

SENHORINHO, H. J. C.; PINTO, R. J. B.; SCAPIM, C. A.; MILANI, K. F.; NIHEI, T. H. Combining abilities and inbreeding depression in commercial maize hybrids. Semina: Ciencias Agrarias, Londrina, v. 36, n. 6, p. 4133-4150, 2015.

VENCOVSKY, R.; BARRIGA, P. Genética biométrica no fitomelhoramento. Ribeirão Preto: Sociedade Brasileira de Genética, 1992. 496 p. 